\title{
Knowledge Relationship With The Status Of Booster Immunization In The Toddler In Community Health Center Pekauman Banjarmasin
}

\author{
Ahmad Hidayat $^{1}$, Desilestia Dwi Salmarini ${ }^{2}$, Dian Pratiwi $^{3}$ \\ \{ayat5621@gmail.com ${ }^{1}$; desilestiadwisalmarini@gmail.com²; \\ ${ }^{1,2}$ Sari Mulia University, Banjarmasin Indonesia \\ *corresponding author: ayat5621@gmail.com
}

\begin{abstract}
Background research on Immunization Booster is an advanced immunization indicated to maintain the level of immune protection threshold above or extend the period of protection. This research aims to know the mother's knowledge of relationships with the status of the completeness of immunization booster on toddlers in the health Pekauman Banjarmasin. Descriptive analytic shaped design research, with the research sample mothers who have toddlers aged 24-36 months totalling 30 people taken Accidental Sampling. The analysis of the test using Kolmogrov Smirnov. The results of the univariate analysis were obtained that knowledge is quite as many as 15 people (50\%) and toddlers complete immunization Booster as many as 18 people $(60 \%)$. Bivariat analysis results obtained value $\mathrm{p}$ value $=0,011(\mathrm{p}<0.05)$ which means there is a relationship between the mother's knowledge with the completeness of immunization Booster.The community health center needs to perform counseling activities to improve the knowledge of the booster immunization when Posyandu in the working area.
\end{abstract}

Keywords: Babies, immunization, Booster Immunization, knowledge

\section{Introduction}

An immunization Booster is an advanced immunization that is indicated to maintain an immune level above the threshold of protection or extend the protection period. Booster is important to improve the immune response of vaccines that have been decreasing as you age. If it is not done, the child is at risk of not being protected when exposed to diseases that should be prevented, such as diphtheria outbreak. If there is an outbreak, re-immunization can be directly administered, in addition to immunization according to the schedule such as the Pentabio given to children aged 18-24 months and the booster measles when the child is 24 months old, special attention should also be given to children School age. When the child is associating with others, more and more chances are the child contracting the disease from his ward (Marimbi, 2010). 
The high mortality rate is strongly influenced by the mother's knowledge of the importance of immunisation including advanced immunization. This lack of knowledge is caused by the lack of available information and socio-cultural conditions (Mitayani, 2010). Knowledge is the result of a person's idea of objects through his or her senses to produce such knowledge greatly influenced by the intensity of attention and perception of objects (Notoatmodjo, 2010). The high mortality rate is strongly influenced by the mother's knowledge of the importance of immunisation including advanced immunization. This lack of knowledge is caused by the lack of available information and socio-cultural conditions (Mitayani, 2010). Knowledge is the result of a person's idea of objects through his or her senses to produce such knowledge greatly influenced by the intensity of attention and perception of objects (Notoatmodjo, 2010).

In the ASEAN region, Indonesia ranks the 4th highest mortality, while according to WHO globally the death rate of toddlers (AKABA) 43 per 1000 births live in the year 2015, Data causes infant death among others caused by Pnemonia $47 \%$ and measles more than $75 \%$ (Article Bascom World edition December 28, 2015). In Indonesia, UNICEF recorded approximately 30,000 - 40,000 children each year suffered from measles attacks.

In Indonesia, the target of the booster's immunization coverage in 2015 amounted to $90 \%$, but from the profile data of Banjarmasin City Health office in 2017 about the access of the booster immunization from 26 Puskesmas, only reached $20.9 \%$ for the booster and $17.0 \%$ for measles Booster from January to October of 2017.

The profile of the health office of Banjarmasin shows that the Puskesmas that has the access of the lowest booster immunization is the health center Pelambuan number $14 \%$ for measles booster and 14\% for the booster Pentabio of 1,771 children, Pekauman Puskesmas amounting to $15 \%$ For the booster Pentabio and $13 \%$ for measles booster of 2,308 children, and Tanjung fence Puskesmas amounted to $9 \%$ for the booster Pentabio and $10.5 \%$ for measles boosters from 544 children. Of the three researchers, the researcher chose Villager Health care because the target number of the most toddler but had a low booster immunization coverage.

Pekauman Puskesmas is a Puskesmas that has the most kelurahan so that it has a target of toddlers who are many but seen from the year 2016 coverage of only $12 \%$ for the booster pentabio immunization and $10 \%$ for measles immunization booster, year 2017 Experienced a slight increase of $15 \%$ for the booster pentabio immunization and $13 \%$ for measles immunization booster, although the increase in the figure was still said to be low.

Based on a preliminary study conducted by researchers on 10 mothers who brought toddlers to Pekauman Health center, after asked questions about the definition of immunization booster, type of booster immunization, and what age is given the immunization booster in the child then Obtained only 3 mothers who know, and 5 mothers who do not know that there is further immunization After basic immunization. As for the 2 mothers who have injected his son immunization booster first, then the researchers are interested to do a research titled Mother Knowledge Relationship with the Status of a completeness of immunization Booster in infants in Pekauman Puskesmas Banjarmasin.

\section{Method}


The study used the design of analytical descriptive research with a cross sectional approach, this type of research aims to find the presence or absence of links between the free variables (knowledge) and the bound variables (completeness status Booster Immunization. The sample used today is the minimum sample of 30 samples.

Sampling techniques taken in Accidental sampling are done by taking the case or the respondent who happens to exist or is available somewhere in the context of the research (Notoadmodjo, 2012). Researchers took the respondent who happened to be the mother who brought his son aged 24-36 months in Puskesmas who encountered researchers when the research was conducted and was willing to be a respondent.

\section{Results}

\subsection{Univariate Analysis}

Table 1 of knowledge distribution of mothers about Booster immunization in Pekauman Puskesmas

\begin{tabular}{lcc}
\hline Knowledge & Frequency & $\%$ \\
\hline Good & 13 & 43,3 \\
\hline Enough & 15 & 50 \\
\hline Less & 2 & 6,7 \\
\hline Total & 30 & 100 \\
\hline
\end{tabular}

From all mothers who are respondents in this research table above can be concluded that most of the respondents have sufficient knowledge about the immunization Booster, namely $(50.0 \%)$.

Table 2 Distribution completeness immunization Booster in Banjarmasin Pekauman Puskesmas

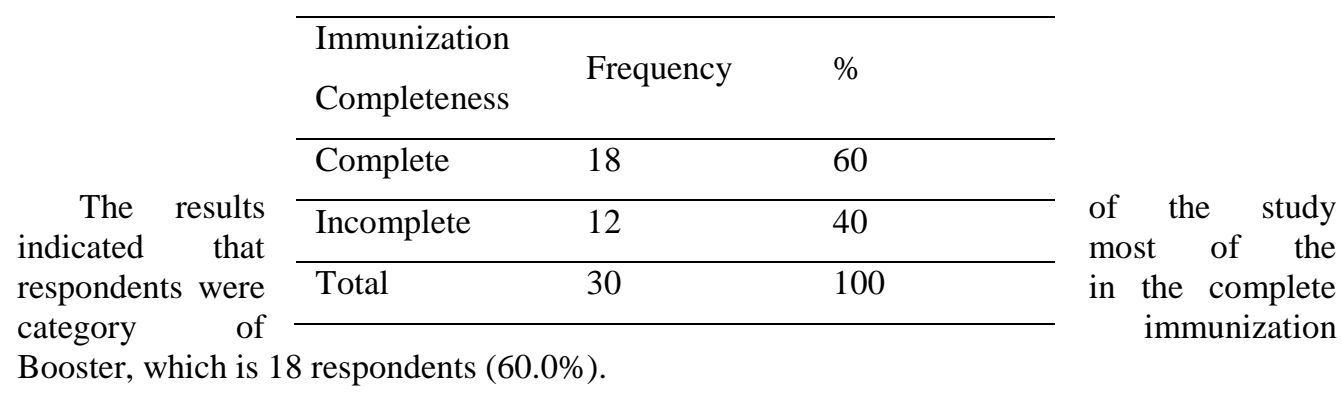




\subsection{Bivariate Analysis}

Table 3. Relations between the knowledge of mothers with the Status of immunization Booster completeness in infants in Pekauman Puskesmas Banjarmasin

\begin{tabular}{|c|c|c|c|c|c|c|c|}
\hline \multirow{4}{*}{$\begin{array}{c}\text { Knowle } \\
\text { dge }\end{array}$} & \multicolumn{4}{|c|}{ Immunization Booster } & & & \multirow{4}{*}{$\begin{array}{l}\text { Pva } \\
\text { lue }\end{array}$} \\
\hline & \multicolumn{4}{|c|}{ Completeness } & \multicolumn{2}{|c|}{ Total } & \\
\hline & \multicolumn{2}{|c|}{ Complete } & \multicolumn{2}{|c|}{ Incomplete } & \multirow[b]{2}{*}{$\mathrm{N}$} & \multirow[b]{2}{*}{$\%$} & \\
\hline & $\mathrm{N}$ & $\%$ & $\mathrm{~N}$ & $\%$ & & & \\
\hline Good & 11 & 84,6 & 2 & 15,4 & 10 & 100 & \\
\hline Enough & 7 & 46,7 & 8 & 53,3 & 15 & 100 & 0,01 \\
\hline Less & 0 & 0 & 2 & 100 & 2 & 100 & 1 \\
\hline Total & 18 & 60 & 12 & 40 & 30 & 100 & \\
\hline
\end{tabular}

From the table 4.3 above, the statistical test results obtained $\mathrm{p}$ value $=0.011$. It shows that there is a relationship between the knowledge variables and the Booster immunization variable $(\mathrm{p}<0.05)$.

\section{Discussion}

\subsection{Univariate Analysis}

\subsubsection{Mother's Knowledge}

The results of analysis of the Univariat knowledge of mothers obtained the results that most mothers have sufficient knowledge of 15 respondents $(50.0 \%)$, mothers with good knowledge as much as $13(43.3 \%)$, and mothers with less knowledge 2 respondents $(6.7 \%)$.

The good knowledge of respondents was demonstrated by the ability of respondents to correctly answer questions relating to the immunization knowledge booster. Mother knowledge is used as the basis to behave in giving immunizations to her children. As for mothers who have good knowledge but do not complement their child immunisation completeness status because of some factors such as the mother who moved to the place of residence so mom forgot to put KIA book that makes MOM cannot monitor and Schedule of immunization grants.

Mother who lives in Pekauman Puskesmas area in Banjarmasin still have a lack of knowledge about immunization because researchers analyze that the level of knowledge of mothers who have toddlers in Banjarmasin Pekauman Puskesmas influenced By the lack of information resources in the community and the participation of health workers or Posyandu cadres should be more monitoring so that residents want to immunize their children. Experience 
is also an incident that has been experienced by individuals both in themselves and from their environment. The experience that will be inherent to the individual knowledge is subjective so that more experience and more knowledge gained more and more. In terms of information, the ease of obtaining information from various sources through health promotion media or the Internet can also improve knowledge.

\subsubsection{Immunization Booster for Toddlers}

The results of the analysis of Univariat immunisation equipment obtained the research that most of the respondents fully immunize their children, which amounted to 18 respondents $(60 \%)$ For full booster immunization and 12 respondents (40\%) The immunization of his son is incomplete immunization is an effort to provide immunity in infants and children by inserting vaccines into the body so that the body makes anti-substance to prevent against certain diseases (Hidayat,2009).

The purpose of this immunization is to be formed so that the risk of experiencing the disease is smaller and expected that the child becomes immune to the disease so as to reduce the number of mortality and mortality And can reduce disability from certain diseases (Hidayat,2009).

There are two types of immunization, including active and passive immunization. According to Hidayat (2009), active immunization is the administration of germs or toxins that have been weakened or turned off with the aim to stimulate the body to produce antibodies themselves. Examples are polio immunization and measles. While passive immunization is the injection of a number of antibodies so that the level of antibodies in the body increases. For example on the injection of ATS (Anti Tetanus Serum) in people who are injured. Another example is that found in newborns where the infant receives various types of antibody from his mother through the blood of the placental during pregnancy, such as antibodies to measles.

The complete immunization Booster is the administration of immunization booster $1 \mathrm{x}$ and measles $1 \mathrm{x}$ before the 3 -year-old. The administration of immunization booster is given at least 12 months after pentabio immunization and can be administered within the range of 18-36 months, the administration of measles booster is given at least 6 months after giving the last measles immunizations and can Given in the age range of 24-36 months, children over 36 months who have not had a completely of immunity should still be given a complete basic munization (KIA book, 2016).

In the master table, there are three categories of color: white, yellow, and red. White color indicates the right age of the toddler to perform booster immunization, where the age of 18 months for the booster Pentabio and 24 months for measles booster. Yellow color Indicates the age of the toddler who is still allowed to immunize booster, red color indicates a toddler who does not immunize the booster. The factors that cause mothers to not complement the completeness of immunization of their children, among them mothers who do not know about advanced immunization is due to perhaps the lack of information obtained his mother about the immunisation booster, mother Children should be in the Immunization but the toddler is sick, mothers who forget about the immunization schedule that has been set this may occur the busyness of his parents so as not to observe the immunization of his children and family habits to move the place Stay so forgot the schedule for immunization. 


\subsection{Bivariate Analysis}

\subsubsection{Relationship with the status of immunization in the toddler in Banjarmasin Pekauman Puskesmas.}

The results of the analysis of the relationship between the level of knowledge and the completeness of the booster immunization in infants aged 24 months-36 months can be explained that from 2 mothers with less knowledge that does not give the complete Mom Man (38.9\%) And as many as 11 mothers (61.1\%) Also the complete immunization of his son. The results of the statistical test obtained ( $p$ value $=0.011$ ) with a rate of $95 \%$ can be concluded there is a relationship between knowledge with the completeness of Booster immunization.

This results in accordance with the research results from Nurazizah (2012) with the title of knowledge of mothers about booster immunization in children in the city of Makasar that shows that there is influence on the knowledge of parents as much as $70.4 \%$ and mother's work Affects the knowledge of mothers, mothers who work better than mothers who do not work all of this is due to mothers working outside the home more easily have access to information.

Based on the results of the study, questionnaire question number 3 is about the composition of the vaccine and question number 14 about the schedule for immunization booster is asked by most respondents wrong in answering the question. It can be concluded this is the cause of the existence of mothers who have not completed the completeness of the booster immunization status in his child due to the lack of knowledge of mothers about the schedule giving immunization The composition of vaccine containing antigens in the form of virus and bacteria are weakened that serves to make anti-body resistant substances useful to maintain to remain immune and can ensure children are difficult to get infected. As for questionnaires questions the respondents were much correct in answering is question number 1 and 2 about immunization and benefits, so it can be concluded that most respondents know that there is further immunization after basic immunization and from mother knowledge about the benefits of advanced immunization. Make the motivation and willingness of mothers to strive to complement the balms immunization.

Completeness of immunization Booster will arise with the suitability of reaction to certain stimulus is knowledge of boosterr immunization. According to Rogers in Notoadmodjo (2003), a behaviour based on knowledge will be longer than behavior that is not based on knowledge. According to Bloom, that the formation of a new behavior begins in the cognitive domain, in the sense that the subject first knows the stimulus of the material or object, thereby raising new knowledge of the subject and subsequently Creates an inner response in the form of a subject's attitude toward the known and fully realized object will lead to a further response that is action (action) in relation to the known stimulus.

Researchers analyze that knowledge is not always gained from high levels of education, because knowledge can also be gained from the mass media, personal experiences and experiences of others, as well as participation from healthcare officers.

Researchers advised Pekauman Health Center to further increase the efforts of increasing public knowledge on immunization by improving counseling-education in the form of health training about the importance of immunization Activities. 



\section{References}

[1] Agus Riyanto. Aplikasi Metodelogi Penelitian Kesehatan. Yogyakarta: Nuha Medika. (2009)

[2] Arikunto. Prosedur Penelitian Suatu Pendekatan Praktek. (Edisi Revisi). Jakarta: PT Rineka Cipta. (2010)

[3] Budiman, A Dan Riyanto, A. Kuesioner Dalam Penelitian Kesehatan. Jakarta: Salemba Medika. (2013)

[4 ]Buku KIA. Buku kesehatan ibu dan anak. Jakarta: Kementrian Kesehatan RI. (2016)

[5] Effendi, Ferry Dan Makhfudli. Keperawatan Kesehatan Komunitas. Jakarta: Salemba Medika. (2009)

[6] Esti Y dan R.Topan. Metodologi Penelitian Dan Statistik. Banjarmasin: In Media. (2014)

[7] Gay, L.R dan Diehl, P.L. Reseach Methods For Business And Management. New York: MacMillan Publishing Company. (1992)

[8] Green, W, Lawremce.Et.Al. Health Education Planing A Diagnostik Approach. The Johns Hapkins University. Amerika Serikat: Mayfield Publishing Company. (2005)

[9] Gunarso, Singgih D. Dasar Dan Teori Perkembangan Anak. Jakarta: PT. BPK Gunung Mulia. (1990)

[10] Hidayat. A.A. Pengatar Ilmu Kesehatan Anak Untuk Pendidikan Kebidanan Jilid Pertama. Jakarta: EGC. (2009)

[11] Hidayat. A.A. Metode Penelitian Kesehatan Paradigma Kuantitatif. Jakarta: HealtBooks. (2010)

[12] Hidayat.A.A. Metode Penelitian Keperawatan Dan Teknik Analisis Data. Jakarta: Salemba Medika. (2012)

[13] Kementrian Kesehatan RI. 2014. Imunisasi Efektif Menekan Angka Kesakitan Dan Kematian Bayi. [Internet]. Tersedia dalam: Retrieved From Depkes RI http://www.Depkes.Go.Id/Article/Print/1239/Imunisasi-Efektif-Menekan-AngkaKesakitan-Dan-Kematian-Pada-Bayi.html. [Diakses 22 Maret 2015].

[14] Lapau, B. 2015. Metodelogi Penelitian Kesehatan: Metode Ilmiah Penulisan Skripsi, Thesis Dan Disertasi. Jakarta: Yayasan Pustaka Obor Indonesia.

[15] Lockhart A dan saputra L. Asuhan Kebidanan Kehamilan Fisiologis \& Patologis. Tanggerang Selatan: Binarupa Aksara. (2014) 
[16] LPPM. Panduan Tugas Akhir Akademi Kebidanan Sari Mulia Dan Sekolah Tinggi Ilmu Kesehatan Sari Mulia Banjarmasin. Banjarmasin: Akbid Sari Mulia Banjarmasin. (2017)

[17] Machfoedz. Metode Penelitian Kuantitatif Dan Kualitatif. Yogyakarta: Fitramaya. (2012)

[18] Marimbi. Tumbuh Kembang, Status Gizi Dan Imunisasi Dasar Pada Balita. Yogyakarta: Nuha Medika. (2010)

[19] Marta, IB. Hubungan Pendidikan Dengan Informasin, Jakarta: Balai Pustaka. (1997)

[20] Maryunani, A. Ilmu Kesehatan Anak Dalam Kebidanan. Cetakan Pertama. Jakarta: CV. Trans Info Medika. (2010)

[21] Mitayani. Buku Saku Ilmu Gizi. Jakarta: Trans Info Media. (2010)

[22] Mubarak, W.I. Promosi Kesehatan Untuk Kebidanan. Jakarta: Salemba Medika. (2012)

[23] Notoadmodjo, S. Pengantar Pendidikan Dan Ilmu Perilaku Kesehatan. Yogyakarta: Andi Offset. (1993)

[24] __. Ilmu Perilaku Kesehatan. Jakarta: Rineka Cipta. (2010)

[26] _. Metode Penelitian Kesehatan. Jakarta: Rineka Cipta. (2012)

[27] Nurazizah. Gambaran Pengetahuan Ibu Tentang Imunisasi Booster. Makasar: KTI.(2012)

[28] Nursalam. Pendekatan Praktis Metodologi Penelitian Ilmu Keperawatan. Jakarta: Sagung Situ. (2001)

[29] _. Proses Dan Doukumentasi Keperawatan, Konsep Dan Praktek. Jakarta: Salemba Medika.(2011)

[30] Profil dinas kesehatan. Capaian imunisasi booster pada baduta. Banjarmasin: Data Dinas Kesehatan. (2017)

[31] Ranuh,I.G.N. Pedoman Imunisasi Di Indonesia. Edisi Ketiga. Jakarta: Badan Penerbit Ikatan Dokter Anak Indonesia. (2008)

[32] Riyadi, Dkk. Asuhan Keperawatan Pada Anak, Edisi 1. Yogyakarta: Graha Ilmu. (2009)

[33] Sugiyono. Metode Penelitian Kuantitatif, Kualitatif dan R\&D. Bandung: CV.Alfabeta. (2013)

[34] Supartini. Buku Ajar Konsep Dasar Keperawatan Anak. Jakarta: ECG. (2004)

[36] Suririnah. Buku Pintar Merawat Bayi Umur 0-12 Bulan. Jakarta: PT. Gramedia Pustaka Utama. (2009)

[37] Sutomo B.. Menu Sehat Alami Untuk Balita \& Batita. Jakarta: PT. Agromedia Pustaka.(2010) 
[38] WHO. World Health Statistic. Geneva. [Internet]. Tersedia dalam: http://www.who.int/gho.com. [Diakses 13 Desember 2015]. (2015)

[39] Widjaja, Mencegah Dan Mengatasi Demam Pada Balita. Yogyakarta: Kawan Pustaka. (2008) 